\title{
American Exceptionalism? U.S. Working-Class Formation in an International Context: Commonwealth Fund Conference, 1995
}

\author{
Caroline Johns and Don Guttenplan \\ University of London
}

The 1995 Commonwealth Fund Conference drew some of the world's leading labor historians and others for two days of extremely lively discussion. Several of the papers took on contentious issues that provoked spirited debate; it is a perhaps a measure of how irritating and yet influential the concept of "American exceptionalism" still is that many of the points raised remained unresolved at the end of the conference.

Marcus Rediker and Peter Linebaugh kicked off the proceedings with their paper "Notes on The Tempest and the Origins of Atlantic Capitalism," in which they explored the ways that working-class identity and consciousness were articulated both within the play and in the larger "Atlantic world." Their detailed and teasing analysis of Shakespeare's text underscored the potential value of shifting the conventional frame of working-class history back a century or two. Peter Thompson, using the same time scale for his paper on the "moral economy" of the Atlantic world, in echoing E. P. Thompson's famous phrase looked at some examples of sailors who had faced "maritime famine"-most notably those instances in which sailors had been compelled to eat their crewmates for survival.

David Roediger and James Barrett ("Inbetween Peoples: Race, Nationality and the New Immigrant Working-Class") argued that in order to imbue the study of race and racism with significance, a meaningful chronological context is necessary. Theirs was a lengthy and wide-reaching look at the implications and effects on immigrants of their racial identity and cultural assimilation into white American society. Following hot on their heels, James Grossman took this a step further in his paper "'Social Burden' or 'Amiable Peasantry': Constructing a Place for Black Southerners" and made it clear that the "place" in question here concerned geography far less than the construction (by white American society) of a social location or a place within society, which would depend on African Americans' acceptance of that place and the concomitant status it would bestow upon them.

In her paper "Present at the Creation: Working-Class Catholics in the United States," Leslie Woodcock Tentler sought to correct the so-called failure of labor historians to attend to religion, "particularly as positive force in working-class life." Pointing out that while Protestants have always constituted a substantial majority in the United States, the working class 
has long been heavily Catholic. Tentler argued that Catholicism was central "in the creation and sustenance of ethnic and working-class communities in the U.S." Urging greater attention to religion per se by labor historians, she described the local church as a "genuinely popular institution," adding that "for many immigrants, the first New World experience of large-scale collective action came in the context of parish creation."

Two papers focused on World War II. Roger Horowitz chided labor historians for constructing narratives in which workers "disappear" on entering the armed forces, "and reappear . . . later, as if military service was a parenthesis in their lives." Horowitz called for a recognition "that the military experience has been a central influence on the process of workingclass formation, especially among men." Quoting extensively from the documents of enlisted men and veterans, Horowitz sought to further the development of analytic tools to understand the impact of military service. But some of his claims - "the combination of the patriotic war rhetoric, and direct participation by GIs in a war against fascism and intolerance, encouraged returning veterans to adopt an unusually cosmopolitan perspective"-seemed speculative. As we know, most returning Gls did not end up in Gideon's Army.

Peter Alexander's more modest examination of South African wartime experience showed that, at least on the home front, the war did score some gains for a more cosmopolitan sense of working-class identity. Tracing a rise in strikes and other forms of labor militancy throughout the war, Alexander illustrated growth in both multiracial and African trade unionism as among the war's most significant consequences. Listing "a number of similarities between the labor histories of South Africa and the United States during this period-overall union growth, increased female and nonwhite participation, extensive collaboration between labor leaders and government"-Alexander was unable "to support contentions that either the American or the South African working-class was exceptional," a conclusion echoed by Robert Gregg. Though his oral presentation lacked cohesion, Gregg's paper on exceptionalism and "The Comparative Histories of the United States and South Africa" stimulated lively discussion. Reviewing the seismic shifts in recent South African history, Gregg asked why "the comparative study of the United States and South Africa never revealed the possibility of such shifts." Lamenting the extent to which even Eric Foner's comparative analysis in Nothing But Freedom "falls foul of the nationalist tendency," Gregg sketched a series of similarities between U.S. and South African gold mining, prostitution, and populism/Afrikaner nationalism. From the floor, Shula Marks offered further instances of parallel development in both class formation and categorization of racial identityfor example, the classification of Jews as "whites"-to support Gregg's thesis that "American working-class formation around ethnicity, race and gender is not so exceptional." Instead, Gregg described exceptionalism as "an imperial formation" whose continued currency owed to America hav- 
ing "exceptional historians" whose collaboration with empire was both unchallenged and unacknowledged.

This would have been a worse blow to any surviving exceptionalists at the conference had not Michael Zuckerman already convicted them of the graver crime of woolly-mindedness. "American exceptionalism," declared Zuckerman, flirting dangerously with self-fulfilling prophecy, "is a subject that reduces smart people to prattle." Yet Zuckerman went on to disprove his own hypothesis with a shrewd review of the "mortification" of recent literature on the topic in his paper and a suggestive presentation of the debate over exceptionalism as a largely symbolic struggle, where the real stakes-America's imperial project-were obscured in rhetorical smoke.

The centerpiece of the conference was the Commonwealth Fund Lecture, delivered this year by Ira Katznelson, entitled "Rhythms of History: Periodicization and American Exceptionalism." Katznelson's paper, a thorough trawl through the political theory surrounding the concept of exceptionalism, focused in particular on the works of Thomas Cochran and Louis Hartz. Katznelson attempted to refurbish Hartz by supplying a context which he clearly believes that Hartz is lacking, but he took pains to emphasize also that without the kind of "supple attention to liberalism's grammar" that could be provided neither by Hartz nor students of political realignment theory, there could be no meaningful periodization of American history. In the end, Katznelson joined most delegates in foreseeing "a decisive farewell to American exceptionalism."

Viewing the conference as a whole, however, it seems clear that any "farewell" to exceptionalism was certainly less than decisive, and the issue will live to be debated another day. Many of the conference papers will be available in a forthcoming publication edited by conference organizers Rick Halpern and Jonathan Morris.

\title{
1994 Social Science History Association
}

\author{
Kim Geiger and Andrew Grossman \\ New School for Social Research \\ Roger Horowitz \\ Hagley Museum and Library
}

The 1994 Social Science History Conference in Atlanta once again offered a number of panels crossing disciplinary boundaries between history and the social sciences. This year's conference showcased some of the innovative work on the American military that combines the political scientist's traditional preoccupation with "guns and bombs" with the social history of 